\title{
POSTER
}

\section{Defining Digital Theology}

\section{Barthian Reflections on the Role of Open Access and Electronic Publishing in the Theological Toolkit}

\section{Race MoChridhe}

University of Wisconsin-Milwaukee

\begin{abstract}
As a student member of the Atla Press Coordinating Council, the presenter has spent the past eight months evaluating, developing, and implementing digital tools to support the Press's initiatives in open access scholarship. This session frames those efforts in the context of theology's status as a "minor participant" (Hutchings 2015) in the digital humanities as well as the emergence of a trans-disciplinary domain increasingly identified as “digital theology" (Phillips 2014). Drawing on Anderson's (2018) analysis of theology's disciplinary distance from the main body of digital humanities work, the presenter outlines a case for the distinctive primacy of digital publishing tools and open access commitments in digital theology, as compared with the broader suite of research tools and methods that constitute the "cultural capital" (Schroeder 2016) of digital humanities as generally understood. Particular attention is paid in this regard to Karl Barth's vision of a "proclamation-centered" (Hector, 2015) theological method as the basis for an ecclesiological critique of closed access publication models.
\end{abstract}


Anderson examined digital humanities not just as a toolkit but as "cultural capital" arising from its community of practice, elaborating how theologians and biblical scholars "exist at the 'margins' of the digital humanities," separate from a culture around "tools for linking data, mapping, network analysis, text mining, and visualizing information that are fueling digital scholarship in other disciplines." ${ }^{1}$ While theologians are very active in digital libraries/archives, these are increasingly seen as the low-hanging fruit of the field as software like Omeka reduces the need for coding skills, and the relative absence of theology from the lists of projects driven by computational analysis results in a cultural divide among practitioners.

A division between theology and the humanities is not a new idea, however. For Karl Barth, theology was the discipline by which the church holds itself accountable for the integrity of its proclamation, ensuring that the word it preaches remains identical with the Word given by God in Christ Jesus and conveyed through the apostolic tradition. ${ }^{2}$ Crucially, this meant that theology "does not have to begin by finding or inventing the standard by which it measures. It sees and recognizes that this is given with the church.” ${ }^{3}$ To submit theological inquiry to the standards of evidence or the methodological rules of either the humanistic or the scientific disciplines was, for Barth, a violence against the unique nature of theological inquiry-a nature necessitated by the transcendentally unique nature of its object. “Theology along these lines," he wrote in his Church Dogmatics, referring to theology practiced according to the academic standards and methods of the humanities or the sciences, "must be flatly disowned as theology. ... Whatever may be the concept of science [Wissenschaft, which in German includes the humanities], this object of knowledge cannot be handled in this way." Many scholars, including Hector, have therefore opined on the need for a Barthian theology to have an ethnographic component that can keep theological work closely connected with the pastoral and proclamational life of the church in its varying contexts. The other half of that communication, howeveri.e. the mechanisms by which the work of theologians is transmitted back to the church to produce "accountability"-has been relatively neglected in the literature. 
Meanwhile, Anderson and Squires examined the religious rhetoric and motifs in open access advocacy, observing that:

[w] hen academics draw on this [religious] tradition ... they do so rhetorically, without methodically addressing substantive historical connections or analogical correspondences....[W]e identify a theological imaginary operating in open access discourse rather than a proper theology. ${ }^{4}$

The question is thus invited, is there a "proper theology" of open access? And, if so, does it have a special role to play in defining digital theology, as distinct from its general presence in digital humanities?

From a Barthian perspective, an argument can be made that "digital theology" should not be understood as a sub-discipline of DH, but rather as a distinct field of endeavour. While theology certainly draws upon the computational tools that define $\mathrm{DH}$, actual use patterns of those tools in studies such as those of Hutchings, Anderson, and Schroeder suggest that they are far less central to theological work than to humanities disciplines. The robust representation of theology in digital library and archives projects might therefore be better understood as reflecting the centrality to digital theology of toolkits and cultural practices that foster engagement with ministerial professionals and broader faith communities-a significance that differs qualitatively from the town-and-gown outreach of the humanities, insofar as theology is not simply benefitted by, but actually defined by, such engagement. Within the scope of Barth's understanding of the discipline, if the outputs of theological work are not available to the church to critique its proclamation on a practical level, the work done is not theology at all. The emerging digital theology community may therefore benefit from considering OA as constitutive of its community of practice in a fashion parallel to, but distinct from, that in which computational analysis has formed the core "cultural capital" of DH. 


\section{ENDNOTES}

1 Clifford Anderson, "Digital Humanities and the Future of Theology,” CURSOR_ 1 (2018, July 24). https://cursor.pubpub.org/ pub/anderson-digitalhumanities-2018.

2 K. W. Hector, "Theology as an Academic Discipline: Reconciling Evangelical Theology and Theological Encyclopedia," in Karl Barth and the Making of Evangelical Theology: A Fifty-Year Perspective, edited by C. B. Anderson and B. L. McCormack (William B. Eerdmans Publishing Company, 2015), 93.

3 Quoted in Hector, “Theology as an Academic Discipline,” 94.

4 Talea Anderson and David Squires, "Open Access and the Theological Imagination,” Digital Humanities Quarterly 11, no. 4 (2017). 